\author{
永禄 6 年と天正13年の式年遷宮について \\ 一中世伊勢神宮の造営組織に関する研究その 4 - \\ REBUILDING PROJECTS FOR ISE-JINGU IN THE EIROKU ERA (1563) \\ AND THE TENSHO ERA (1585) \\ - A study on construction organization of the medieval Ise-Jingu Part 4-
}

浜島一成*

\title{
Kazunari HAMAJIMA
}

\begin{abstract}
For the rebuilding in the Eiroku era(1563), a contract price was determined in each of principal phases of the project of the Shoden. The contract prices for buildings other than the Shoden were separately determined for those buildings. For the rebuilding in the Tensho era(1585), on the other hand, the total contract price was fixed first and was then taken into consideration for determining the number of buildings to be constructed and other items.
\end{abstract}

Keywords : ISE-JINGU, Carpenters, Contract, the late 16th century

伊勢神宮，建築工匠，請負，16 世紀後期

\section{1.はじめに}

本研究は、中世伊勢神宮における作所や神宮工の活動内容の実態 を検証し、その造営組織としての特色を明らかにするもので、本稿 はその第 4 稿にあたる。

これまで、神官等によって組織された作所・小作所と呼ばれる造 営組織の性格や、その影響のもと編成された神宮工(嗔工・頡代・小工 ）の系譜等について検討し、さらに、14・15 世紀における伊勢神宮 社殿の請負工事の実態について検討した ${ }^{1)}$ 。

ところで、伊勢神宮では、式年遷宮が 15 世紀中期から 100 年以上 にわたり中断し、その中断の後の 16 世紀後半に行われたものとして、 永禄 6 年 (1563) の外宮式年遷宮と天正 13 年 (1585) の内・外両宮 の式年遷宮がある。永禄 6 年の式年遷宮は、天文 20 年 (1551) の慶 光院清順の勧進が契機となり、天文 24 年正月に本宮 5 社殿（正殿・ 東西宝殿·御错殿·外幣殿）と瑞垣、一〜三八鳥居の造営が決まり工 事が始まるが、永禄元年 (1558) に正殿の立柱・上棟が行われた後は、 資金難のため工事は遅れ、ようやく永禄 6 年 9 月に正遷宮が行われ る ${ }^{2)}$ 。一方、天正 13 年の式年遷宮は、慶光院周養の勧進に対し、天 正 10 年 (1582) に織田信長が造営費用の寄進を行い、さらに、その 信長の志を継いだ豊臣秀吉も造営費用の寄進を行い、天正 13 年 10 月に正遷宮が行われる。
上述のように、永禄 6 年や天正 13 年の造営工事は、それまでの工 事と異なり、勧進僧(尼) 主導によるものである。そして、大河直躬 博士は、中世における大規模な工事の中で、請負が認められる実例 として、永禄 6 年の造営工事を挙げる。大河博士は、伊勢神宮では、 中世前期において、工匠の出勤日数によって賃金が支給されるのに 対し、この造営工事では、賃金の総額をあらかじめ決定して請負う 形態であり、しかも請負は手間賃のみで、材木·飾り金具等の材料は 含まれず、また、頭工と小工の集団が請負うと指摘する ${ }^{32}$ 。

ところが、伊勢神宮では、既に $14 \cdot 15$ 世紀において、正殿以外の 殿舎に「請屋」つまり請負が行われるものの ${ }^{4)}$ 、この永禄 6 年や天 正 13 年の造営工事では、正殿についても請負が行われる。そこで本 稿では、まず、永禄 6 年の式年遷宮について、その造営工事の経過 が詳述された「永禄記」 ${ }^{5)}$ をもとに、正殿と正殿以外の殿舎に分け、 各殿舎の請負状況を工事の進行にあわせて検討寸る。次に、天正 13 年の式年遷宮について、織田信長・豊臣秀吉が寄進した造営費用が 神宮工に支払われた経過や、また、支払われた名目や金額等を整理 し、さらに、それら造営費用の使途について検討する。以上、両造 営工事を詳細に検討することにより、16 世紀後半期の式年遷宮にお ける請負の実態について一考察を試みる。

本稿は, 平成19年の日本建築学会学術講演梗概集で発表した内容に, 新たな知見を加えて論述したものである。

* 日本大学理工学部理工学研究所 研究員.工博 Researcher, Research Institute of Science and Technology, College of Science and Technology, Nihon University, Dr. Eng. 


\section{2. 永禄 6 年の式年遷宮}

(1) 正殿の工事について

正殿では、山入（造営用の料材を杣山から切り出寸作業）や、木 作始、立柱・上棟といった主要な工事の区切りごとに請負金額を決め る。そこで、主要工事ごとにその経過を記す。

（イ）山入

天文 24 年（1555）正月 27 日に、作所より山入料を 500 貫文との 申し出があったが、神宮工はそれに同意せず、4月 16 日に 700 貫文 （山入り前に 500 貫文、材木が宮中に到着時に 200 貫文）で同意す る。

ところで、山入料が 700 貫文と決まるものの、「外宮解」に ${ }^{6)}$ 、

一、天文廿四年四月十四日、正遷宮山口祭アリ、祭主下向アッテ

六十二月武学用

常之祭礼之儀職ニテ神事アリ、従清順上人、頭工 三千貫之約

束ニテ、本宮五社 $\square \square \square$ 中カキ鳥居迄請取、御木作始、弘治三 年六月八日二執行也（中略）山口祭ヨリ木作始二至迄、先千百 貫之分作所へ渡ル、則頭工請取

とあり、4月 14 日の山口祭に関する記述から、神宮工は正殿等の一 連の工事を 3000 貫文で請負ったことがわかる。また、山口祭から木 作始にかけて、作所から神宮工へ1100 貫文支払われたとある。これ は、後述するように、木作始が 400 貫文で請負われるため、山入料 と木作始を合算した金額と考えられる。

さらに、永禄元年（1558） 5 月9 日条に、

（前略）此日去年四百貫之内、四十五貫作所預りさん用有、七百

貫渡、口ぬき廿一貫引、京任料廿三貫七百五十文引、山入五十

貫、口ぬき壱貫五百引、其他又京より壱貫御つけ、合四十六貫 二百五十文也（後略）

とあり、山入料 700 貫文の他に、さらに山入料 50 貫文が記されてお り、作所と神宮工の合意した山入料に補充がなされたといえる。そ のため、4月 16 に合意した山入料 700 貫文は、あくまでも工事費の 概算であり、工事費用を制限するものではなかったといえる。

（口）木作始

弘治 3 年 6 月 7 日に、作所の申し出のとおり木作始が請負額 400 貫文で合意し、翌 8 日に木作始の祭儀が行われる。そして、弘治 3 年 6 月 11 日には、工事費の一部が神宮工に支払われる。

ところで、同年 12 月 25 日条に「相残四十五貫作所預り也」とあ り、工事費の残り 45 貫文を作所が預かったことがわかる。そして、 前に引いた永禄元年 5 月 9 日条から、山入料 700 貫文の口抜き 21 貫文 ${ }^{7)}$ に、任料 23 貫 750 文之、山入料 50 貫文の口抜き 1 貫 500 文 を加えた 46 貫 250 文の作所得分に、この預かった 45 貫文を宛てた ことがわかる。

(八) 立柱·上棟

永禄元年 3 月 20 日条の「御立柱上棟勘文副状」には、立柱を 4 月 13 日、上棟を立柱と同日もしくは 6 月 23 日に行う陰陽頭勘文が記 されるが、この後暫くは、立柱上棟に関する記述は見出せない。し かし、永禄元年 5 月 2 日条に、「三百五十貫文にて同心申」とあり、 その後、正殿の立柱・上棟に関する記事が続くため、立柱・上棟が請
負額 350 貫文で合意したと考えられる。結局、立柱は 6 月 19 日、上 棟は 6 月 23 日に行われる。

また、永禄元年閏 6 月 16 日に、作所が神宮工へ 100 貫文を渡した 際に「御ふき、ミつかきまてのやくそく有」と記されており、5月 2 日条の「同心申」には、正殿と瑞垣の屋根莫き料も含まれていた 可能性がある。この後、正殿等の屋根工事は大幅に遅れ、永禄 6 年 7 月 2 日より再開寸る。しかし、その再開直前の永禄 6 年 (1563) 6 月 29 日に、萱葺師が作所へ莫賃を要求する。作所は、請負金額 3000 貫文中に莫賃が含まれると始めは拒否したが、後に、莫賃 4 貫 500 文のうちの 2 貫文を負担する。

（2）瑞垣·東宝殿·西宝殿·御饌殿·外幣殿の工事について

永禄 2 年 3 月の「外宮解」 8$)$ に「右御造替之事、就被仰出、既本 宮御立柱、上棟如形奉造立之処、依御造料未足、東西宝殿其外于今 事不相調之条」とあり、正殿は主要部の工事が完了するが、正殿以 外の東・西宝殿等は未だ工事が始まっていないことがわかる。以下、 正殿以外の殿舎について検討する。

（イ）瑞垣

永禄 2 年正月 16 日に、作所から小工人、昨年瑞垣の請負額を 50 貫文としたが ${ }^{9)}$ 、清順上人がこの件について知らないため、瑞垣と 東宝殿合わせて請負額 100 貫文の申し出がなされるものの、合意に 至らない。

しかし、2月 20 日条に「小工壱貫当二同心候」とあり、また「( 2 月）廿六日より御作事有、小工壱貫つつ請取也」とあることから、 作事に際し小工 1 人当たりに 1 貫が支給されたことがわかる。後述 寸るように、東宝殿は単独で工事されたため、瑞垣のみの工事で何 らかの合意がなされたと推測される。

（口）東宝殿

永禄 2 年 8 月 3 日条に、

御作事可レ有之由御申、然者作所御気殿可レ然之由被レ申候処、 小工衆五百貫請取候者可乞仕二て候、東宝殿可乞然之由にて事す み候、二百貫可-請取_こ一候、此内又鍛冶三十五貫可一請取_之 由申候間、作所種々被レ申候て、(後略)

とあり、500 貫文が御饌殿単独の請負額を示すかどうか文意が不明 確である。しかし、東宝殿の請負額は 200 貫文で、しかもこの内 35 貫文が鍛冶分といえる。この東宝殿の場合、他の工事と異なり鍛冶 工の請取額が明記される。これは、正殿の立柱直前であった永禄元 年 5 月 20 日条に「鍛冶屋過分二代請取可レ申之由申候間、延引也、 御作事もなき也」とあり、鍛冶工が多額の請取を要求し、工事が延 期となったことがある ${ }^{10)}$ 。そのため、事前に鍛冶工への支払い額を 決めたと考えられる。

\section{(分) 西宝殿·御错殿·外幣殿}

永禄 3 年 6 月 28 日、作所は頭工衆に対して、西宝殿・御饌殿の請 負金額 400 貫文に、さらに 100 貫文を加えた合計 500 貫文で、西宝 殿・御饌殿・外幣殿を請負ように申し出を行う。工事は、7月より 始まるものの遅々として進まず、結局、中断する。工事が再開し、 本格的に進み始めるのは、禁裏から慶光院清順へ正遷宮費用 2 万正 
が下される永禄 6 年 5 月以降である。前述したように正殿の 屋根工事等も再開され、9月 23 日に正遷宮となる。

以上まとめると、14·15 世紀の「請屋」では、正殿以外の 殿舎を請負の対象とするのに対し、永禄 6 年の式年遷宮では、 造替された全ての殿舎が請負の対象となる。そして、作所と 神宮工の話し合いにより、まず、造営工事全体の請負金額の 概算が決められる。次に、工事の進行状況に合わせて、正殿 の山入、木作始、立柱・上棟といった重要な工事の区切りごと に、改めてそれぞれの請負額が作所と神宮工の話し合いによ り決められ工事が進む。一方、正殿以外の殿舎では、瑞垣と 東宝殿が、請負金額の決定後すぐに工事が始まるのに対し、 西宝殿·御饌殿・外幣殿は、3 社殿一括で請負額が決まるもの の、資金難のため工事に遅滞が生じ、工事完了が大幅に遅れ る。

\section{3. 天正 13 年の式年遷宮}

（1）織田信長・豊臣秀吉の造営費用の寄進 ${ }^{(11)}$

織田信長により、天正 10 年 2 月 3 日に内・外宮合わせて 3000 貫文の造営費用の寄進が行われ ${ }^{12)}$ 、これをもとに、4月 3 日に外宮・内宮の順に山口祭が行われる ${ }^{13)}$ 。造営工事では、 内・外宮とも、神宮工に山入料 700 貫文と祝料 (頭工 2 貫文 · 頭代 1 貫 500 文・小工 1 貫支）が支払われる ${ }^{14)}$ 。この造営工 事は、6月に起きた本能寺の変により中断する。

豊臣秀吉は、天正 12 年 3 月 23 日に、内・外宮に合わせて 金子 500 枚と米 1000 石を寄進する旨を申し出るが ${ }^{15)}$ 、それ に先立ち 3 月 17 日に、周養上人に内・外宮造営のための金子 250 枚を渡す ${ }^{16)}$ 。しかし、御師上部貞永の横領により、実際 に内・外宮に下された金子は 85 枚（内宮 43 枚、外宮 42 枚） である ${ }^{17)}$ 。そして、内・外宮それぞれ頭工方に金子 35 枚 ${ }^{18)}$ と「大工補任料」 ${ }^{19)}$ を支払っており、全体の 8 割以上の支出 が神宮工関連である。また、天正 13 年 2 月 16 日に、米 1000 石が内・外宮に下されるが、内宮分の遣口は、木工の作料・ 飯米料・雲形料等が 450 石、鍛冶等の作料・飯米料等が 50 石となり、建築工匠関係が約半分を占める ${ }^{20)}$ 。

式年遷宮の祭儀が終了した天正 13 年 11 月に、内·外宮ごと に式年遷宮に関する算用状が作成される。内宮には、工事費 として総額で金子 125 枚・米 3200 石が寄進され、そのうち神 宮工一金子 100 枚・米 1000 石が支払われる ${ }^{21)}$ 。また、外宮 には、工事費として総額で金子125枚・米2800石が寄進され、 そのうち神宮工へ金子 100 枚・米 1000 石が支払われる ${ }^{22) 。 し た か ゙ ~}$ って、両宮合わせた総工事費は、金子 250 枚・米 6000 石、銭に換算 すると約 11000 貫となる ${ }^{23)}$ 。そして、神宮工への支払額は、内・外 両とも同額の、銭に換算して約 3000 貫文となる。

\section{（2）造営費用の使途}

天正 12 年の内宮一禰宜荒木田守豊の書状に

一、参千貫文にて御造営申合段、作所并頭工方方、いかほとにて 成共、承分候との申事候、御造料二したかひ宮数并宮立之様躰 可有之事也、件之定义之事 ${ }^{24)}$

とあり、作所と頭工等の話し合いにより、内宮の造営工事の請負金
表 1 天照皇太神宮御造営之注文 (天正12年12月)

\begin{tabular}{|c|c|c|c|}
\hline & 費 & 延べ人数 & 作 \\
\hline 1 & 御山入料 & & 700貫文 (金子35枚) \\
\hline 2 & 正殿 & 3500 人 & $\begin{array}{l}350 \text { 貫 (針料・足代料を } \\
\text { 号) }\end{array}$ \\
\hline 3 & 東宝殿・西宝殿 & 3000 人 & 300貫 \\
\hline 4 & 瑞垣 & 2000 人 & 200貫 \\
\hline 5 & 瑞垣南御門 & 500 人 & 50貫 \\
\hline 6 & 蕃垣御門 & 300 人 & 30貫 \\
\hline 7 & 玉串御門 & 700 人 & 70貫 \\
\hline 8 & 南第四御門 & 500 人 & 50貫 \\
\hline 9 & 瑞垣西御門 & 400 人 & 40貫 \\
\hline 10 & 北御門 & 400 人 & 40貫 \\
\hline 11 & 内院御鳥居削り立て 3 ケ所 & 100ずつ(300人) & 30貫 \\
\hline 12 & 一鳥居・二鳥居 (黒木) & 30 ずつ(60人) & 6貫 \\
\hline 13 & 御材木小屋 大工請取 & & 30貫 \\
\hline 14 & 鍛冶小屋 & & 30貫 \\
\hline 15 & 読合小屋 & & 10貫 \\
\hline 16 & 木㫣き届ける骨折り料等 & & 90貫 \\
\hline 17 & 芋縄・布綱料 & & 20 貫 \\
\hline 18 & 布・役人の食料等 & & 20貫 \\
\hline 19 & 御萱 (3000荷) ・荁葺の際の神事料 & & 60貫 \\
\hline 20 & 鍛冶作料、鉄 & & $\begin{array}{l}240 \text { 貫（鍛冶作料 } 120 \\
\text { 貫、鉄 } 120 \text { 貫） }\end{array}$ \\
\hline 21 & 陸电料 & & 120貫 \\
\hline 22 & 宮地普請料 & & 50 貫 \\
\hline 23 & 諸役人の祭料（14ヶ度） & & 350貫 \\
\hline 24 & 大工の祭料（13ヶ度） & & 130貫 \\
\hline 25 & 仮の御樋代、神宝入れの曲物 & & 15貫 \\
\hline 26 & 心御柱 (神事料も含む) & & 10貫 \\
\hline
\end{tabular}

1 26の分 3021貫

\begin{tabular}{|c|c|c|}
\hline & 荒祭宮 & 200貫（材木・作料） \\
\hline 28 & 荒祭宫の絹・布 & 10貫 \\
\hline 29 & 外幣殿 & 100貫（材木・作料） \\
\hline 30 & 御稲倉 & 100貫（材木・作料） \\
\hline 31 & 御供調所 & 100貫（材木・作料） \\
\hline 32 & 酒殿 & 50貫（材木・作料） \\
\hline 33 & 一の殿 & 50貫（材木・作料） \\
\hline 34 & 子良館 & 250貫（材木・作料） \\
\hline 35 & 正殿の飾り絹36疋他 & 32貫 700 文 \\
\hline 36 & 東西宝殿の飾りの絹等 & 7貫 \\
\hline 37 & 鏡宮 & 5貫（材木・作料） \\
\hline & 神主装束料他 & 60貫 \\
\hline
\end{tabular}

額が 3000 貫文と決まったことがわかるが、この金額は、前節で検討 した神宮工に支払われた金額と一致する。そのため、この造営工事 では、まず工事費の総額を決め、次に、その金額に見合った数の殿 舎を工事し、また、殿舎の「様射」25) も工事額に合わせて決められ たと推測される。

また、同年 12 月に作成された「天照皇太神宮御造営之注文」（以 下「注文」と略す） ${ }^{26)}$ を一覧にしたのが表－1である。「注文」に よると、正殿・東西宝殿・瑞垣・諸門・鳥居等については、工匠の 延べ人数をもとに作料つまり手間賃が記されるのに対し、荒祭宮・ 外幣殿・御稲倉等では作料と材木費の合計が記される。つまり、正 殿・東西宝殿及び諸門等は、14・15 世紀と同様に手間賃が支給され 
る手間請負が行われるのに対し、それ以外の殿舎では、式年遷宮と しては始めて、手間賃と材料費の一括支給を受ける請負が行われた と考えられる ${ }^{27)}$ 。

さらに、「注文」には、山入料として 700 貫文（金子 35 枚）が記 される。永禄 6 年の外宮式年遷宮でも、山入料 700 貫文が支払われ、 織田信長の寄進による造営工事の際にも、山入料 700 貫文が支払わ れる。この 700 貫文が、山入に際して神宮工に支払われる一つの目 安であったのだろう ${ }^{28)}$

ところで、『天正十三年造営記』の天正 13 年 8 月 22 日条には、

$$
\text { ( 遷宫時 祭) (此) }
$$

（前略）内宮正せんくうのときまつりの料弐十九、このうち十四 (調)

まつり八、大工方への参千貫のうちにてととのい可レ申候八ん (残) (執行奉) かと存候、のこる十五祭の御神事、有様ニとりをこなひたてま (此跡) (筧) (邆)

つるへき事(中略)このあとのくわん正三年の正せん宮の時の、

(執 行)

(分)

とりをこなハれたるふんなり（後略）

とある。これは、寛正 3 年（1462）の内宮式年遷宮以前の造営工事 について記したものである。この造営工事は、造営費用が 3000 貫で、 遷宮の際に行われる祭儀の数が、「注文」より 2 つ多い 29 であるな ぞ、天正 13 年の造営工事と類似点がある。そして、その 29 の祭儀 の中で、神宮工が関係する 14 の祭儀費用を造営費用 3000 貫の中か ら払うと記す。一方、「注文」では、正殿・東西宝殿及び諸門等の工 事総額（3021 貫文）とそれ以外の殿舎の工事総額（924.7 貫文）が 別々に計上され、両者を合わせると、神宮工が請負った金額よりも 1000 貫文近く多い。おそらく「注文」は見積書であるため ${ }^{29)}$ 、実際 の工事費より多く見積った可能性が高い。例えば「注文」では、遷 宮に関わる祭儀 27 全ての費用を見積るが、実際には、上述した寛正 3 年以前の造営と同様に、神宮工が関係した祭儀のみの費用が支出 されたと推測される。

さらに、『天正十三年造営記』同日条の後半の、天正 13 年の造営 工事について記した部分に、
(宮加)
(届)
(鹿 海)

(前略) 両度一度二御木をととくるにより、宮川よりかのめ川 (眇)

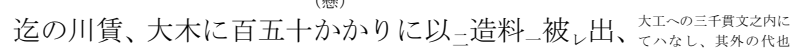

(後略)

とあり、内・外宮の造営工事が同時期に行われたため、臨時的に内 宮の料材を宮川より鹿海川まで運ぶ川賃が必要となり、その費用が、 3000 貫以外の経費から支出されたことがわかる。つまり、請負額 3000 貫は、通常の造営費用のみを意味し、臨時的な支出については、 それ以外の経費から支出したといえる。

以上のように、天正 13 年の式年遷宮は、作所と神宮工の話し合い によって総工事費が 3000 貫文と決められ、その工事額に合わせて、 工事を行う殿舎数やその「様躰」が決まる。また、造営費用 3000 貫文は、神宮工が担当する祭儀の費用等を含むものの、臨時支出と なる料材の運送費等は含ない。さらに、正殿・東西宝殿及び諸門等 は、従来からの手間請負が採用されるが、それ以外の殿舎では、式 年遷宮としては始めて、手間賃と材料費の一括支給を受ける請負が 採用される。

\section{4. まとめ}

永禄 6 年と天正 13 年の造営工事では、造営費用が乏しいため、作 所と神宮工の話し合いにより、まず造営工事全体の請負金額 3000 貫文が決められる。その際、14・15 世紀の「請屋」のように、正殿 以外の殿舎を請負の対象とするのではなく、造替する全ての殿舎を 請負の対象とする。

そして、永禄 6 年の造営工事では、正殿に関しては、山入、木作 始、立柱・上棟といった重要な工事の区切りごとに、改めてそれぞれ の請負額が決められ工事が進むが、正殿以外では、殿舎ごとに個別 あるいは一括して、改めて請負金額が決められる。これは、清順上 人による勧進活動が捗らず、そのため、造営費用の収集額に応じて 工事が進められたためと推測される。一方、天正 13 年の造営工事で は、信長・秀吉等による造営費用の寄進により工事額が既に定めら れ、その工事額に合わせて、工事を行う殿舎数やその「様射」が決 められる。造営費用には、神宮工が担当する祭儀の費用等は含まれ るが、臨時支出にあたる料材の運送費等は含まれない。

ところで、永禄 6 年の造営工事や、天正 13 年の正殿や東西宝殿等 の造営工事では、従来からの手間請負が採用される。しかし、天正 13 年の造営工事の終盤にかけて行われた上記主要殿舎以外の工事 では、手間賃と材料費の一括支給を受ける請負が、式年遷宮として は始めて採用される。これは、天正 13 年の造営工事が、永禄 6 年の ように、工事の停滞期に禁裏等から造営費用の寄進を受けるといっ たような、造営費用の増額が見込めないことから、残りの殿舎につ いては、手元に残った造営費用で工事を完成させるため、神宮工に 手間賃と材料費の一括支給を行ったと考えられる。

尚、16 世紀以降の神宮工の系譜についての検討は別稿を予定して いる。

本稿は、平成 19 年度科学研究費補助金 基盤研究 (C)「室町時代 〜江戸時代前期における建築工匠の系譜と活動形態に関する基礎的 研究」の研究成果の一部である。

注

注 1 ) 拙稿 (1)「作所・小作所の性格と神宮工の大工職補任について一中世伊 勢神宮の造営組織に関する研究 その 1 -」日本建築学会計画系論文 集 543 号 2001 年 5 月、(2)「神宮工の大工職継承の実態について一中 世伊勢神宮の造営組織に関する研究 その 2 -」日本建築学会計画系 論文集 554 号 2002 年 4 月、(3)「神宮工の大工職併有と「請屋」「請 工」について一中世伊勢神宮の造営組織に関する研究 その 3 -」日 本建築学会計画系論文集 591 号 2005 年 5 月」。後に、拙著『中世日 本建築工匠史』相模書房 2006 年に所収。

注 2 ) 福山敏男「神宮の建築とその歴史」『神宮』小学館 昭和 58 年。

注 3 ）大河直躬『番匠』法政大学出版局 1978 年 $\mathrm{p} 171$ 。

注 4）前掲注 1 拙稿(3)及び、拙著第 2 部第 2 章第 4 節参照。

注 5 ) 『神宮遷宮記』第 4 巻所収。以下、第 2 章において「永禄記」からの引 用史料については出典を略す。尚、「永禄記」の筆録者は作所松木忠彦 である。

注 6 )「外宮天文引付」35 (『三重県史』中世 1 (上) (以下『県史』と略す))。 ところで、「伊勢神宮頭工等申状写」(「退蔵文庫旧蔵神宮関係古文書」52 『県史』中世 1 (下)）に「然者三千貫文之内七百貫文、御山入料二ひき て、残式千三百貫文之内ノわり二て御座可有と存候」とあり、3000 貫文 
から山入料 700 貫文を引いた 2300 貫文を神宮工で分配すると記される。 また、「外宮頭工等申状案」(「退蔵文庫旧蔵神宮関係古文書」72『県史』 中世 1 (下)) では、「外宮正遷宮清順上人御造料、永楽三千貫文請取申 候、此払口、千四百八拾貫五百文、御材木何か二遣申候、残千五百十九 貫五百文、頭・頭代・小工分口之事」とあり、52 号文書に記された金額よ りも少ない 1519 貫 500 文を神宮工で分配すると記す。この文書には、「御 材木何か二遣申候」とあり、払口（1480 貫 500 文）の中に、材木費が含 まれるかのような記述内容である。両文書とも年号が久落し、両文書の 前後の内容から、中世末から近世初めにかけて作成された文書と推測さ れる。そのため、両文書の信憑性は低く、上記内容については今後の検 討課題としたい。

注 7 ） 口抜料とは、造営工事等の際に作所が得る仲介手数料のことか。700 貫文に対する口抜料は 21 貫文であり、費用の $3 \%$ 程度と考えられる。

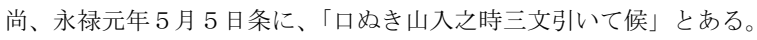
注 8 )「外宮引付」44（『県史』中世 1 (上))。

注 9 )「永禄記」永禄元年の各条には、瑞垣を 50 貫文で請負う記述は見出せ ない。「永禄記」の久落部分に記されたものか。

注 10）永禄元年 6 月 1 日に 80 貫文、同月 13 日に 130 貫文を鍛治工に提示し たが合意せず、結局 160 貫文で合意する。

注 11）織田信長・豊臣秀吉の造営費用の寄進については、従来、史料に即し て明確に論じられることが少なかった。中西正幸氏は、「秀吉も金子五 百枚と米千石とを、それぞれ両宮遷宮費として寄進した。（中略）造営 料六千五百貫文は定額よりもはるかに少なく」（同氏著『神宮式年遷宮 の歴史と祭儀』大明堂 1995 年 47 頁）と記すが、小島鉦作氏は、6500 貫は神宮側が造営費注文に記した控えめの額であり、秀吉はこれを上回 る「造営料として一万貫と金子五百枚を供進している。」述べる（同 氏著『伊勢神宮史の研究』小島鉦作著作集第 2 巻 吉川弘文館 1985 年 281 頁及び 290 頁)。小島鉦作氏は、『天正十三年御遷宮記』天正 13 年正月 22 日条の「従_秀吉_一万貫御下行、金子五百枚可。有_御渡_由、 先五千貫文之通御代付を以、金子武百五十枚請取申由」から上述のよう に造営費用が「1 万貫と金子 500 枚」と解しているが、これは引用箇所 の後半部分からもわかるように「1 万貫分として金子 500 枚分を渡す」 と解す心゙きである。尚、秀吉は上記引用箇所にもあるように、金子 500 枚を寄進すると表明するが、実際には、本節で取り上げる天正 13 年 11 月の算用状から、内・外宮あわせて金子 250 枚しか寄進していない。以 上のように、織田信長・豊臣秀吉の造営費用の寄進状況等については、 幾つかの錯誤がある。そのため、本節では、史料に即しながら寄進状況 の確認作業も併せて行う。

注 12)「外宮天正遷宮記（異本）」(『神宮遷宮記』第 4 巻 国書刊行会 平成 4 年所収)。

注 13)「外宮天正遷宮記」(『神宮遷宮記』第 4 巻 国書刊行会 平成 4 年所収)。

注 14)「天正十三年御遷宮記」(『神宮遷宮記』第 4 巻 国書刊行会 平成 4 年所 収)、「外宮遷宮用途料算用状」(『県史』中世 1 (下) 1999 年 第 2 部 慶 光院文書 85$)$ 。

注 15）「外宮天正遷宮記（異本）」尚、島津義久も、（天正 13 年力） 5 月 16 日
に銀子 1000 両を寄進する。（「島津義久寄進状」『県史』中世 1 （下）」 第 1 部 文書 27 )

注 16）「羽柴秀吉消息（折紙）」（慶光院文書 78）。

注 17)「天正年中記録」天正 12 年 3 月 24 日条（『三重県史』中世神宮関係資 料 補遺 2000 年 第 2 部 記録 1 ) 尚、横領された金子 165 枚（内宮: 82 枚、外宮 : 83 枚) は、天正 13 年正月 28 日に下される（「両宮遷宮料 請取鸴」慶光院文書 82 )。

注 18) 内宮:「周盖上人・内宮一襧宜荒木田守豊連署書状写」(慶光院文書 183)、 外宮 :「周養上人 - 外宮一襧宜度会貴彦連署書状写」（慶光院文書 79）

注 19）内宮では金子 1 枚、外宮では 8 両。大工職補任料は、本来、建築工匠 が神宮へ支払う心゙きものである。この場合の「大工補任料」は、神宮が 建築工匠へ支払う祝料等を意味するのかもしれない。

注 20）「内宮一禰宜荒木田守豊請文」(『県史』中世 1 （下）別冊引引付「天正 拾二年より拾六年迄之事」13)。尚、本文に記した以外にも、秀吉から の寄進等があったと考えられる。後述するように、天正 13 年 11 月の算 用状にはその総額が記されるが、寄進の経緯については、本文に記した 以外、史料上確認することは出来ない。

注 21）「周養上人 - 内宮一禰宜荒木田守通連署内宮遷宮料算用状」（慶光院文 書 88）及び「内宮一頭大夫等連署遷宮用途料請取状（折紙）」（慶光院 文書 89)

注 22）「外宮一禰宜・同神主中連署遷宮料算用状」（慶光院文書 91）及び「外 宮頭工等連署遷宮料足請取状（折紙）」（慶光院文書 92）

注 23） 1 石を 1 貫文、金子 1 枚を 20 貫文として概算。

注 24）「内宮一禰宜荒木田守豊書状」（『県史』中世 1 （下）別冊 3 「引付天正 拾二年より拾六年迄之事」一-3)。書状の当該箇所には年月日は記されな いが、この前が天正 12 年 3 月 25 日条であり、後ろが 4 月 15 日頃（こ の条は、頭工に金子 20 枚を渡す記事であり、これは「天正年中記録」 の同日条より確認できる。）とみなされる。そのため、当該箇所は、 3 月下旬から 4 月上旬にかけて記されたと考えられる。

注 25）内宮では、この天正 13 年の式年遷宮により、85 年ぶりに正殿が造営 され、その規模・構造・形式は、古図等をもとに作所と神宮工の話し合 いにより決められたとされる（福山敏男『神宮』小学館 昭和 58 年 127 頁)。造営文書中に「様躰」を説明する記述はないが、福山博士の指摘 する「規模・構造・形式」のことであろうか。今後の課題としたい。

注 26)「天正十三年御遷宮記」

注 27）内宮別宮風日祈宮の文明 11 年（1479）遷宮においても、手間賃と材料 費の一括支給を受けた造営工事が行われた。しかし、これは別宮一社だ けの小規模な工事であり、本宮関係の大規模な工事では、天正 13 年の 造営工事が最初といえる。

注 28）天正 10 年の山入から、わずか 2 年後に再び山入りを行う。造営費用の 寄進者が、信長から秀吉に代わったため、再度山入りを行ったのである うか。

注 29）川上貢氏は、注文を「中世に「損色」と同様に見積書と考定される文 書」と指摘する（同氏『日本建築史論考』中央公論美術出版 1998 年 352 頁)。 